\title{
A study in retail sales person effectiveness
}

\author{
M. Birt* \\ School of Management Studies, University of Cape Town \\ Private Bag, Rondebosch 7701, Republic of South Africa \\ mbirt@commerce.uct.ac.za \\ D. Vigar \\ School of Business, University of Natal \\ Private Bag X01, Pietermaritzburg 3209, Republic of South Africa \\ vigard@nu.ac.za
}

Received March 2002

\begin{abstract}
Strategic Management theory suggests the importance behavioural alignment of organisational actors with organisational objectives (Robbins, 1998, Hellriegel, et al. 2001). This study utilises Kelly's Personal Construct theory to examine the similarity of constructs held by four groups of actors in a retailing operation, regional managers, store manageress, sales personnel and customers. The study also compares constructs in appropriate company documentation. The results suggest a lack of similarity between the groups and the groups with Company documentation, it is argued that this lack of alignment would have detrimental effects for the organisation.
\end{abstract}

*To whom all correspondence should be addressed.

\section{Introduction}

The term effectiveness is used extensively to describe organisations, groups and individuals. The view that some organisations, groups and individuals are measurably more effective than others is a bas ic assumption in mainstream economic, organisational and behavioural theory (Robbins, 1992). However, despite its frequent use, there is very little agreement as to what 'effectiveness' means (Hall, 1982; Hodge, Anthony \& Gales, 1996). The dominant view in the literature is typified by Gibson et al's., 2000 (and others) criteria (Cameron \& Wetton, 1983; Steers, 1975; Hannan \& Freeman, 1977; Stoner, 1982) and reflects a management view of the topic. It is possible that the definition of effectiveness held by job holders and the customers they deal with may be different to those of management, and these potentially varying definitions could result in the non alignment of behaviours. 'Based on an interpretation of how we believe we are supposed to behave, we engage in certain types of behaviour.' (Robbins, 1998: 252) Thus, if our interpretations of what make 'effective' behaviour are different, our behaviours will also be different. Such nonalignment could be detrimental to the individual (in terms of stres s) and the group (in terms of a lack of cohesion and poor performance) (Burnes, 2000). Behavioural alignment is accepted as a necessary condition for the efficient implementation of organisational strategy (Robbins, 1998) and for effective group functioning (Greenberg \& Baron, 2000).

Kelly (1963) said, 'man looks at his world through transparent patterns or templates which he creates and then attempts to fit over the realities of which the world is composed'. These templates Kelly calls constructs, and maintains that individuals constantly explore their environments and based on their experience develop a 'mental map' made up of constructs. These constructs channalise, focus and guide behaviour. If role players in organisations hold different constructs of effectiveness then Kelly's Personal Construct Theory (PCT) would suggest less behavioural alignment between organisational actors with potentially negative consequences on organisational performance.

\section{Retail sales person effectiveness}

Retailing is a labour intensive business (Burstiner, 1986; Weitzel, Schmarzkorf \& Peach, 1989; Mason, Mayer \& Ezelle, 1991). In all but the smallest firms, labour costs represent the single largest expense other than 'cost of sales' (Burstiner, 1986; Teas, 1981). The retail industry is characterised by long working hours, relatively inexperienced employees and relatively low wages (Darden, Hampton \& Howell, 1989; Donnelly \& Etzel, 1977). These factors contribute to high rates of labour turnover which in turn increases personnel costs (Spivey, Munson \& Lacander, 1979).

Dubinsky and Mattson (1979) argue that retail sales people have traditionally been seen to play a minor role in the success of retail organisations, they have been characterised as 'order fillers'. Management's focus has been on merchandise, store design, location, advertising and similar issues with the personal selling component of the retail mix receiving less attention (Bellenger \& Goldstucker, 1981). Performance measurements stress objective or productivity related measures such as sales volumes (Kotler \& Armstrong, 2001) and as such focus on outcomes rather than 
behaviours. Dubinsky and Levy (1989) believe that as sales person performance is multifaceted, multiple measures including objective, subjective and behavioural measures should be used in the assessment of retail sales person performance. This argument is supported by Peppers and Rogers (1999). Research on retail sales people suggests that because they perform boundary spanning roles they are likely to experience conflicting expectations (Weatherby \& Tansik, 1994; Goodwin \& Radford, 1993; Hartline \& Ferrell, 1996), and this in turn is likely to lead to role ambiguity (Berry \& Gresham 1986; Cronin \& Taylor 1992). Saxe and Weitz (1992) have argued that role ambiguity is inversely related to sales person performance, whilst others (Dunlap, Dotson \& Chambers, 1988; Kelley, 1992; Westbrook, 1981) have shown role ambiguity to be a major cause of job tension and dissatisfaction. Role conflict, the result of divergent role expectations (Robbins, 1998), has also been found to relate to increased job stress, tension, a lack of interest in the job, a decline in performance and a propensity to leave (Goolsby, 1992. Dubinsky \& Hartley, 1986; Claxton \& Ritchie, 1979; Mathieu \& Zajac, 1990). Wetzels et al (2000) have argued that role ambiguity is negatively associated with organisational commitment and a commitment to service quality.

This research aims to discover whether the groups involved in the retail arena, i.e. regional managers, branch manageresses, sales people and customers have similar constructs of what constitutes sales person effectiveness. Instead of assuming a definition of effectiveness it attempts to establish what 'salesperson effectiveness' means to the different groups. The research also attempts to establish salesperson effectiveness constructs to be found in related organisational documentation such as the job description and training manuals. A strong similarity of constructs between the different role players would suggest an alignment of behaviours which could logically be argued to contribute to improved organisational performance, and vice versa.

This allows for the following hypothesis formulation;

There is a similarity of constructs of sales person effectiveness between the research groups.

(Null) There is no similarity of constructs of sales person effectiveness between the research groups.

\section{Methodology}

Personal Construct Theory and the Repertory Grid technique have a long history, Chetwynd (1974) believes that the Grid technique's adaptability makes it an excellent instrument for research appropriate for many situations. Easterby-Smith (1980) believes that it is "an extremely powerful means to quantify people's attitudes, feelings and perceptions". Easterby-Smith further suggests that the Grid technique can be useful in examining what underlies the judgemental process. The Repertory Grid has been successfully used in many business applications. For example, the Repertory Grid Technique has been used by a training department to see how managers view the various programmes and services offered by the department (Anderson, 1990), and a bank to assess branch managers perceptions of the internal service delivered by head office (Athanassopoulos, 1991). Grids have been used to establish the characteristics that selectors use in their judgments of candidates (Smith \& Stewart, 1977), in vocational guidance and counselling (Smith, Hartley \& Stewart, 1978), in determining the factors used to appraise performance (Stewart \& Stewart, 1976). In the development of cognitive performance appraisals for managers (Dunn, Pavlak \& Roberts, 1987) the analysis of bargaining in industrial relations (Birt, 1991) and in determining the distinctive qualities of successful black managers (Ntsinde, 1995).

Construct Theory deals specifically with people's subjective views of the world but at the same time by way of the Grid technique allows for quantification of results and avoids problems of observer bias (Stewart, 1975). The Grid is a way of mapping constructs identifying the individuals subjective view of the world (or a specific element of their world, in Kelly's terms a 'focus of convenience' (Kelly, 1970) it is these subjective views of reality which are thought to shape behaviour. Personal Construct Theory and the Repertory Grid Technique have been extensively tested and used in industrial and pure psychology contexts in South Africa. (See Zaidel, 1995; Weinberg, 1992; Hugo, 1997; Kotze, 1999.)

\section{The sample}

The Western Cape operation of a national retailer provided the research provenance from which four groups of actors were drawn and sampled. Regional management, store manageresses, sales personnel and customers were interviewed and their constructs of sales person effectiveness were elicited using the construct elicitation process developed by Stewart and Stewart (1976). Constructs are bi-polar and elicited in the words of the respondent and were then used to construct a questionnaire which was distributed to a larger number of respondents in each group. Table 1 below details the number of questionnaires sent to each of the groups and the response rates. Respondents completed the same questionnaire twice: firstly with effective sales persons in mind and secondly with ineffective.

The questionnaires were analysed using Stewart, Stewart \& Fonda's (1981) methodology for Grid analysis. This methodology was used to determine the significance of constructs and the extent of similarity between the groups. Significant constructs are those which pertain to effective sales persons and differentiate effective from ineffective sales persons. 
Table 1: Questionnaire response rates

\begin{tabular}{l|c|c|c}
\hline & $\begin{array}{c}\text { Number of } \\
\text { questionnaires } \\
\text { per group }\end{array}$ & $\begin{array}{c}\text { Response } \\
\text { rate as a } \\
\text { percentage } \\
\text { Effective } \\
\text { questionnaire }\end{array}$ & $\begin{array}{c}\text { Response } \\
\text { rate - } \\
\text { Ineffective } \\
\text { questionnaire }\end{array}$ \\
\hline $\begin{array}{l}\text { Top } \\
\text { Management }\end{array}$ & 7 & 100 & 100 \\
\hline Manageress & 20 & 100 & 95 \\
\hline Sales Person & 60 & 97 & 98 \\
\hline Customers & 200 & 37.5 & 24.5 \\
\hline
\end{tabular}

Method for establishing significant constructs:

1. Calculate the differentiation score for each construct. This indicated the extent to which the construct was used to differentiate effective from ineffective sales people.

2. Calculate a separation score. This score indicated the extent to which the construct was associated with effectiveness.

3. Constructs which satisfied both criteria i.e. which had both high differentiation and high separation scores, and where thus termed significant, were then reported as Summary coefficients. Summary coefficients combined the differentiating and association capabilities of a construct into a single score. These were the constructs which would be compared across the groups.

To calculate the above coefficients the Stewart and Stewart (1976) statistical procedure was followed. The following analysis was done separately for each group.

a) The questionnaire responses were transferred to a master script. There were two master scripts per group. The first master script contained the sum of responses from all the effective questionnaires in the group, and the second master script the sum of the responses from all the ineffective questionnaires.

For example:

Effective Master script for Sales Ladies Group (58 respondents)

$\begin{array}{lcccccc}\text { Construct } 1 & 1 & 2 & 3 & 4 & 5 & \\ \text { Friendly } & 40 & 10 & 8 & 0 & 0 & \text { Unfriendly } \\ \text { Weighted } & 120 & 20 & 8 & 0 & 0 & \end{array}$

Ineffective Master script for Sales Ladies Group (58 respondents)

$\begin{array}{lllrrr}\text { Construct 1 } & 1 & 2 & 3 & 4 & 5 \\ \text { Friendly } & 0 & 0 & 8 & 12 & 38 \\ \text { Weighted } & 0 & 0 & 8 & 24 & 114\end{array}$

Unfriendly

Thus the responses could fall into 5 columns between the two poles of a construct. Thus for the sales lady group, 40 of the respondents said that effective sales ladies would always be friendly (i.e. scoring this construct 1). Ten said that an effective sales lady would not always be friendly, but was more friendly than unfriendly. Eight respondents said she was as friendly as unfriendly. There were no respondents saying that an effective saleslady was either always unfriendly (scoring 5) or mostly unfriendly (scoring 4).

The Ineffective master script indicates that for this construct, 38 of the respondents felt that the ineffective sales lady would always be ineffective and so on.

b) The raw scores on the master scripts were then weighted. This was done to minimise the problem of missing data. Columns 1 and 5 were multiplied by 3 , and columns 2 and 4 by 2 .

c) Next it had to be determined where the highest scores lay for each item (construct) in order to find the extent of differentiation. This represented the extent to which the construct differentiated between the effective and the ineffective sales person. This was the differentiation score, which was calculated by determining for each item, the number of columns between the highest score on the Effective questionnaire and the highest score on the Ineffective questionnaire. Thus, in the example above the highest score on the effectiveness master script for sales ladies was in column 1 . The highest score on the Ineffective mast script for the same group was in column 5 . Thus, this group had 3 columns between the scores. This represented a maximally differentiating construct.

d) The next step was to identify the constructs most strongly associated with effectiveness according to each of the groups. Using the Effective master script, the two right hand columns were added as were the two left hand columns for each item and then the smaller subtracted from the larger. This is the Effectiveness Separation Score. The highest scores indicate the items which are most strongly associated with the effective sales lady i.e. which should theoretically be developed and fostered. Thus in the example above, the calculation would be as follows:

$(120+20)-(0+0)=140$

e) In order to facilitate comparison across the groups, Effectiveness Separation coefficients were calculated. These represented the Separation score as a proportion of the highest separation score for that group. This was necessary because the groups had different sample sizes which obviously affected the separation scores. By reporting these scores as coefficients, the groups could be compared.

f) To combine the association and differentiating capabilities of the construct into one score, a Summary score was calculated. This score was the absolute sum of the Effective and Ineffective 
Separation scores multiplied by the differentiation score. These scores were also reported as coefficients so as to facilitate comparison across the groups. The Summary scores could also be ranked in order to provide an indication of the relative importance of the construct to the particular group in question.

g) For purposes of this study only constructs which both differentiated maximally and which were associated with effectiveness were reported, and these were termed "significant", for lack of a better word.

To further compare group constructs, their significant constructs were categorised using the categories/headings to be found in the job description of a 'sales person'. The categories included administration, selling technique, customer service, customer commitment, selling style, communication skills, job and organisational commitment, manageability, personality and other factors.
Furthermore, utilising the construct eliciting methodology developed by Du Preez (1972) organisational documentation was analysed. These documents were firstly the 'Job Knowledge Assessment and Training Plan' and secondly the 'Job Description'. These documents formed an organisational description of an effective sales person and the significant constructs drawn from this source were compared to those of the different group's constructs. i.e. the relative usefulness of each construct to differentiate effective from ineffective sales persons.

\section{The findings}

\section{Extent of overlap of the groups' constructs}

Table 2 indicates the degree of similarity between the groups when it comes to sales person effectiveness. The table gives the percentages of significant constructs that overlap, i.e. are common to more than one group.

Table 2: Extent of overlap of significant constructs across the groups

\begin{tabular}{|c|c|c|c|c|c|c|c|c|}
\hline & \multicolumn{2}{|c|}{ Manageress } & \multicolumn{2}{|c|}{ Sales person } & \multicolumn{2}{|c|}{ Customer } & \multicolumn{2}{|c|}{ Documentation } \\
\hline \multirow[t]{2}{*}{ Top Management } & \multicolumn{2}{|c|}{7 constructs } & \multicolumn{2}{|c|}{3 constructs } & \multicolumn{2}{|c|}{2 constructs } & \multicolumn{2}{|c|}{1 construct } \\
\hline & $31.8 \%$ & $21.2 \%$ & $13.6 \%$ & $7.5 \%$ & $9.1 \%$ & $4.3 \%$ & $4.8 \%$ & $3 \%$ \\
\hline \multirow[t]{2}{*}{ Manageress } & & & \multicolumn{2}{|c|}{13 constructs } & \multicolumn{2}{|c|}{12 constructs } & \multicolumn{2}{|c|}{5 constructs } \\
\hline & & & $49.4 \%$ & $32.5 \%$ & $36.4 \%$ & $26.1 \%$ & $18.5 \%$ & $16.7 \%$ \\
\hline \multirow[t]{3}{*}{ Sales person } & & & & & \multicolumn{2}{|c|}{15 constructs } & \multicolumn{2}{|c|}{5 constructs } \\
\hline & & & & & $37.5 \%$ & $32.6 \%$ & $15.4 \%$ & $20 \%$ \\
\hline & & & & & & & \multicolumn{2}{|c|}{4 constructs } \\
\hline & & & & & & & $9.1 \%$ & $13.3 \%$ \\
\hline
\end{tabular}

To illustrate what this table shows: there are two constructs which are significant to the Top Management and Customer groups (shaded area). These two constructs represent $9.1 \%$ of the Top Management's (total) significant constructs and $4.3 \%$ of the Customer's (total) significant constructs. Thus with the highest percentage overlap being less than $50 \%$ (49.4\% of the Manageress' significant constructs overlapped with the sales person constructs), it was concluded that the groups are not similar in their views of sales person effectiveness.

Also, if one looks at the extent of overlap between the significant constructs of the groups and those represented by the documentation, the maximum level of similarity is $20 \%$, i.e. between the sales person group and organisational documentation.

\section{Comparison of significant constructs across the groups}

Table 3 presents the percentage of constructs in each of the categories (derived from the sales person job description) for each group. It also gives the percentage of significant constructs in each category. This is the percentage of the total number of significant constructs which fall into that category.

It is important to note the apparent unimportance of categories 1, 2, 6 and 10 across all the groups. These categories neither contain many constructs nor do they contain many significant constructs which differentiate and are associated with effectiveness. 
Table 3: Percentages of constructs and significant constructs by category and group

\begin{tabular}{|c|c|c|c|c|c|c|c|c|}
\hline \multirow[t]{2}{*}{ Category } & \multicolumn{2}{|c|}{ Top Management. } & \multicolumn{2}{|c|}{ Manageress } & \multicolumn{2}{|c|}{ Sales Person } & \multicolumn{2}{|c|}{ Customer } \\
\hline & $\begin{array}{l}\% \\
\text { Total }\end{array}$ & $\begin{array}{l}\% \\
\text { Signif. }\end{array}$ & $\begin{array}{l}\% \\
\text { Total }\end{array}$ & $\begin{array}{l}\% \\
\text { Signif }\end{array}$ & $\begin{array}{l}\% \\
\text { Total }\end{array}$ & $\begin{array}{l}\% \\
\text { Signif. }\end{array}$ & $\begin{array}{l}\% \\
\text { Total }\end{array}$ & $\begin{array}{l}\% \\
\text { Signif }\end{array}$ \\
\hline 1. Administration & 3.45 & 0 & 3.19 & 0 & 4.42 & 2.50 & 0.94 & 0 \\
\hline 2. Selling Technique & 3.45 & 4.55 & 4.26 & 3.03 & 3.5 & 2.50 & 2,83 & 2.1 \\
\hline 3. Customer Service & 1.72 & 4.55 & 11.70 & 18.18 & 14.16 & 10.00 & 28.3 & 28.26 \\
\hline $\begin{array}{ll}\text { 4. Customer } \\
\text { Commitment }\end{array}$ & 3.45 & 0 & 11.70 & 27.27 & 15.04 & 30.00 & 24.53 & 28.26 \\
\hline 5. Selling Style & 8.62 & 9.09 & 15.96 & 15.15 & 14.16 & 7.50 & 13.21 & 15.22 \\
\hline $\begin{array}{l}\text { 6. Communication } \\
\text { Skills } \\
\end{array}$ & 10.34 & 4.55 & 6.38 & 9.09 & 6.19 & 7.50 & 4.72 & 6.52 \\
\hline 7. Commitment & 20.69 & 31.82 & 15.96 & 15.15 & 9.73 & 15.00 & 1,89 & 2.17 \\
\hline 8. Manageability & 24.14 & 22.72 & 9.57 & 6.06 & 15.04 & 12.50 & 1.89 & 2.17 \\
\hline 9. Personality Factors & 18.97 & 18.18 & 15.96 & 0 & 16.81 & 10.00 & 14.15 & 15.22 \\
\hline 10. Other & 5.17 & 4.55 & 3.19 & 6.06 & 2.65 & 2.50 & 0 & 0 \\
\hline $\begin{array}{l}\text { Total number of } \\
\text { Constructs }\end{array}$ & 58 & 22 & 94 & 33 & 113 & 40 & 106 & 46 \\
\hline
\end{tabular}

\section{Discussion}

The findings confirm the null hypothesis i.e.,

The constructs held by top managers, branch manageresses, sales persons and customers with respect to sales person effectiveness, are not the same.

The groups construe the domain of sales person effectiveness differently. Examining the spread of constructs across the categories in Table 3, might lead one to believe that the Manageress, Sales Person and Customer groups share similar views of sales person effectiveness because they all have the largest proportion of their significant constructs in the Customer Commitment category. However, when looking more closely at these significant constructs it becomes evident that the extent of overlap is in fact, very limited. The maximum number of constructs common to more than one group was 15 (Table 2) and this was between the Sales Person and Customer groups. This only represented $37.5 \%$ of the Sales Persons' significant constructs and $32.6 \%$ of the Customers' significant constructs. None of the groups shared similar views on their most important construct, and these constructs did not even fall into the same categories. On top of the low overlap rate, where constructs are common to more than one group, they are often not of similar usefulness to the group in differentiating between effective and ineffective sales persons. In other words they have lower
Summary scores. For example, the significant construct She chats to the customer, i.e. makes conversation. - She only greets the customer, which is common to both Manageress (Construct 58) and Sales Person (Construct 57) groups, is very useful to the Manageress group (coefficient of .99) and yet only moderately so for the Sales Person group (coefficient of .76).

\section{Construct profiles of an effective sales person}

\section{Top management}

The majority of the Top Management group's significant constructs on sales person effectiveness fell into the categories of Manageability (22.72\%), Commitment (31.82\%), and Personality Factors (18.18\%). The Top Management felt that to be effective the sales person must be totally committed to the job, the store and the organisation and do things for the love of the job rather than expectation of extra extrinsic rewards.

Manageability to the Top Management group meant being easily motivated, trainable, being able to learn quickly and being able to be given additional responsibilities. It is important to note here that the constructs which are significant to the Top Management group do not seem to focus on the sales person's functioning as a sales person but rather on potential and trainability for future posts. The orientation also appears to be internal i.e. focused on the 
functioning of the organisation rather than external and focused on the customer and customer satisfaction.

\section{Manageress}

For the manageress group, Customer Commitment (27.27\%), Customer Service (18.18\%), Commitment $(15.15 \%)$ and Selling Style $(15.15 \%)$ are important. Taking the two customer related categories (Customer Commitment and Customer Service) together, this means that almost every second construct which differentiates between effective and ineffective sales persons and which is strongly associated with effectiveness deals with some aspect of customer relations. This is extremely significant when compared to the Top Management percentages for these same groups ( $0 \%$ and $4.76 \%$ respectively - see Table 2$)$.

Four of the Manageress group's top 10 constructs were in the Customer Service category. The most important of these was that the sales person offer the customer help when she enters the store i.e. before the customer asks for it. This was seen by the Manageress group as the most important construct when describing sales person effectiveness. According to the Manageress group this offer must follow directly from the sales person approaching and greeting the customer (Construct 29).

An effective sales person approaches, greets and offers the customer help before the customer initiates the sales encounter. The sales person must also be consistently helpful to the customer (Construct 62). In order to do this, the sales person must always be alert for the customer even if she is involved with other activities such as unpacking new stock

It is also important to note that almost one in three significant constructs used by the Manageress group belong to Category 4 which calls for extra effort on the part of the sales person. This category contains constructs which refer to more than just a customer orientation. These constructs deal with the extra attention the sales person provides to the customer. For the Manageress group, the most important constructs in this category require the sales person to go out of their way for the customer and for example, phones other branches if the required item is not available in the store, and that the sales person makes conversation with the customer in order to determine her specific needs.

\section{Sales person}

For the sales person group, the most important category was that of Customer Commitment $(30 \%)$ (Table 3$)$. This category had 3 of the group's top 10 significant constructs including the construct, She goes out of her way for the customer. Nothing is too much effort - Everything is an effort. She does nothing extra (Construct 45). This construct was the most important to the Sales Person group in terms of differentiating between effective and ineffective behaviour. For this group, 'going out of your way' for the customer meant phoning other branches for required items that weren't available in the store, making the customer feel special, and making conversation with the customer so as to get to know her.
The next category in terms of proportion of significant constructs, is that of Commitment $(15 \%)$. There is thus a realisation that effectiveness in the sales person job requires commitment to job, company and customer. Both previously mentioned groups have attributed importance to this category although particularly the Top Management group. However, comparing the views on Commitment across the Top Management and Sales Person groups, the only construct they have in common is the need for the sales person to be enthusiastic about the job. The emphasis in the Sales Person group is more on the level of effort expended. According to this group, it is important for a sales person to be hard working, serious about her job and always busy with something. A construct that is significant to the Sales Person group and which is not mentioned as significant to the Management Groups is that of the sales person enjoying her job. This was ranked $4^{\text {th }}$ by the Sales Person group, and is especially relevant because the same construct was ranked by the Customer group to be the most important construct in terms of differentiating between effective and ineffective sales personnel.

\section{Customer profile of an effective sales person}

For customers, as may be expected, this group had very few or no constructs in the categories Administration, Manageability, Commitment, Selling Technique and Other. There were only four categories of any real relevance in terms of the spread of constructs: Customer Service and Customer Commitment both with $28.57 \%$, and Personality Factors and Selling Style both with $15.22 \%$ of the constructs (Table 3 ). In other words, nearly $60 \%$ of the constructs fall into the two customer-oriented categories. These results are not surprising. It was not really expected that customers consider the sales persons' administrative activities, manageability, or commitment as important to effectiveness or in differentiating between effectiveness and ineffectiveness. It is also not surprising that more than 1 in 4 of the customers' significant constructs came from the Customer Commitment category as this category includes behaviour above and beyond what is expected in terms of customer service.

The Customer Group's perception of what was required for effective Customer Service included that the sales person greet the customer on entry to the store, that they remain attentive to dealing with their needs, that the help offered be useful, and that the advice given be good. However, the most important thing to the Customer group was that the sales person at least appear to be happy to serve i.e. that they look and act as though they enjoy their work. There are some important differences between the Customer understanding of Customer Service and that of the other groups. The first is on the issue of 'helpfulness'. The Customer group were not as concerned about whether the help was offered but whether it was in fact useful. And this ties in with the construct dealing with the value of advice the sales person gives. To be effective the help must be useful and the advice good. Merely offering help and advice doesn't make a sales person effective. While the Manageress and Sales Person groups said that the sales person should be alert for the customer and be there when the customer needed them, the Customer group was more 
concerned about whether the sales person remained attentive or became distracted when dealing with the customer. Effective sales persons according to the Customer group, remain attentive to the customer irrespective of how long assistance is required.

In terms of Customer Commitment, the most important construct was the construct, She goes out of her way to help the customer. - She does her job and no more. To the Customer group, this means that the sales person is genuinely interested in her and her needs. The sales person must spend time with the customer, getting to know her specific needs and then find something to satisfy those needs. That might require being in attendance in the fitting rooms to return or exchange items, checking in the storeroom, phoning other branches, or even suggesting other stores. It also means making the customer feel welcome and special and having her best interest at heart. This last construct touches on the honesty issue. Customers feel that the sales person must tell her if a garment does not suit her and not only try to sell what is most expensive or high fashion.

Also, the Customer group felt that the sales person must tell customers about, and encourage them to come in for, upcoming sales. The important difference between these constructs and the ones held by the other groups in the same category is that these emphasise an attitude or predisposition of genuine interest from which flows an ability to satisfy the customer's needs. It isn't enough to go through the motions according to organisational manuals definition of the selling process e.g. approach, greet, offer help etc. The interest in the customer must be genuine and the help must be useful

\section{Organisational documentation}

The constructs of the four groups are not the same as those elicited from the documentation concerning the sales person and her job.

By far the most important category in terms of the spread of constructs elicited from the documentation was the Administration category with $56.7 \%$ of all constructs falling into this category. This can be compared to $0 \%, 0 \%, 2.5 \%$ and $0 \%$ for the Top Management, Manageress, Sales Person and Customer groups respectively (Table 2). This category included activities required for point-of-sale and microfiche operation, stock handling, housing and security. The only overlapping construct in this entire category was the Sales Person group construct dealing with the need for the sales person to be alert to what was happening in the store. Even this construct did not make direct reference to security. Security functions are seen as key responsibilities of sales personnel the Job Description and yet were not accorded any significance by either of the management groups. The fact that these administrative duties make up four fifths (or 36.5 out of 54 training hours) of the Training and Evaluation document, and yet are not seen as significant at all by any of the groups is evidence enough of the lack of similarity amongst the groups' views on sales person effectiveness and the picture portrayed by the documentation provided by the company.

\section{Discussion}

The conclusions drawn from the findings have some serious implications for the management of sales persons in this firm. Kelly (1963) argues that an individual uses his/her construct system to interpret the environment and then regulates his/her behaviour according to these interpretations (Adams-Webber, 1979). It is the individual's constructs which govern what the individual does - how s/he behaves. Thus the individuals in each of the groups in this study will behave in ways based on their constructions of their environment. Inconsistent constructions of what is effective for the sales person, will potentially lead to a host of dysfunctional activities, and reduce the organisations ability to perform effectively. Customers may be dissatisfied with the sales person's behaviour because the sales person does not do what the customer expects of an 'effective sales person'. This may result in customer defections and negative word of mouth. Managers, both store, and regional, will select, train and reward behaviour consistent with their constructions of effective sales person behaviour. The sales people will deliver the service they construe as being effective. They are likely to experience both role conflict and role ambiguity. Such a nonalignment of behaviours can only be dysfunctional for the organisation.

The logic of strategic planning suggests that organisational objectives are more likely to be achieved where organisational behaviour is co-ordinated, focused and aligned with those objectives. Organisational change theorists, Hamlin, Keep \& Ash, (2001); Nelson \& Coxhead, (1997); Harvey \& Brown, (2001), emphasise the importance of identifying the required behaviours and communicating these to all organisational players. Change agents therefore need to determine the required behaviours which will achieve the organisational objectives, and then align behaviours to achieve these behaviours. Internal alignment is a characteristic of the strategy of learning organisations. (Hellriegel et al., 2001). Such internal alignment means that the management and employees of an organisation share the same views of what is required by each member to achieve individual, departmental and organisational effectiveness. In other words, different groups within the organisation would share similar constructs of what is required for effective performance. Different construct sets in significant groups of organisational actors is likely then to impact negatively on organisational effectiveness.

\section{References}

Adams-Webber, J.R. 1979. Personal construct theory: Concepts and applications. Chichester:John Wiley \& Sons.

Anderson, N.R. 1990. 'Refertory grid techniques in Employee selection', Personnel Review, 19(3):9 - 15.

Athanassopoulos, I. 1991. 'Branch managers' perceptions of head office service'. MBA dissertation, Graduate School of Business Administration, University of the Witwatersrand. Bellenger, D.N. \& Goldstucker, J.I. 1981. Retailing basics. Homewood ILL: Irwin. 
Berry, L.L. \& Gresham, L.G. 1986. 'Relationship retailing: Transforming customers into clients', Business Horizons, November - December: 43-47.

Birt, M. 1991. 'The structuration of industrial relations in the S.A. Clothing Industry, 1968 - 1986'. Unpublished PhD. Thesis, University of Cape Town.

Bitner, M.J., Booms, B.H. \& Tetrealt, M.S. 1990. 'The service encounter: Diagnosing favourable and unfavourable incidents', Journal of Marketing, 54, January: 71 - 84.

Burnes, B. 2000. Managing change: A strategic approach to organisational dynamics, $3^{\text {rd }}$ Edition. New Jersey: Pearson Education.

Burstiner, I. 1986. Basic retailing. Homewood, ILL: Irwin.

Cameron, K.S. \& Whetton, D.A. 1983. Organisational effectiveness: A comparison of multiple models. San Diego, Calif: Academic Press.

Chetwynd, J. 1974. 'Generalised grid technique and some associated methodological problems'. Unpublished $\mathrm{PhD}$ thesis, University of London.

Claxton, J.D. \& Ritchie, J.R. 1979. 'Consumer prepurchase shopping problems: A focus on the retail component', Journal of Retailing, 55, Fall: 24 - 43.

Cronin, J.J. \& Taylor, S.A. 1992. 'Measuring service quality: A re-examination and extension', Journal of Marketing, 56, July: $55-68$.

Darden, W.R., Hampton, R. \& Howell, R.D. 1989. 'Career vs organisational commitment: Antecedents and consequences of retail sales peoples' commitment', Journal of Retailing, 65(1):80 - 106.

Donnelly, J.H. \& Etzel, M.J. 1977. 'Retail store performance and job satisfaction: A study of anxiety-stress and a propensity to leave among retail employees', Journal of Retailing, 53(2): 23 - 28.

Dubinsky, A.J. \& Hartley, S.W. 1986. 'Antecedents to retail sales person performance: A path-analytical perspective', Journal of Business Research, 14: 153 - 268.

Dubinsky, A.J. \& Levy, M. 1989. 'Influence of organisational fairness on work outcomes of retail sales people', Journal of Retailing, 62(2): 221 - 252.

Dubinsky, A.J. \& Mattson, B.E. 1979. 'Consequences of role conflict and ambiguity experienced by retail sales people', Journal of Retailing, 55, Winter: $70-86$.

Dunlap, B.J., Dotson, M.J. \& Chambers, T.M. 1988. 'Perceptions of real-estate brokers and buyers: A salesorientation, customer-orientation Approach', Journal of Business Research, 17:175 - 187.
Dunn, W.N., Pavlak, T.J. \& Roberts, G.E. 1987. 'Cognitive performance appraisal - Mapping, manager's category structures using the grid technique', $P R, \mathbf{1 6}$ : 16-19.

Du Preez, P.D. 1972. 'The application of Kelly's Personal Construct Theory to the analysis of political debates', Journal of Social Psychology, 95: 267 - 270.

Easterby-Smith, M. 1980. 'The design, analysis and interpretation of repertory grids', International Journal of Man-Machine Studies, 13: 3 - 24.

Goodwin, C \& Radford, R. 1993, 'Models of service delivery: an integrative perspective', Advances in Services Marketing and Management, 2, 231 - 252.

Goolsby, J.R., 1992. A theory of role stress in boundary spanning positions of marketing organizations. Journal of the Academy of Marketing Science, 20, 155 - 164.

Greenberg, J. \& Baron, R. 2000. Behaviour in organizations. $7^{\text {th }}$ Edition. Upper Saddle River, New Jersey: Prentice Hall.

Hall, R.H. 1982. Organisations: Structure on process. Englewood Cliffs, New Jersey: Prentice Hall.

Hamlin, R., Keep, J. \& Ash, K. 2001. Organisational change and development. Essex: Pearson Education.

Hannan, M.T. \& Freeman, J. 1977. 'The population ecology of organisations', American Journal of Sociology, 82: 929 964.

Hartline, M.D. \& Ferrell, OC.C. 1996. 'The management of customer contact service employees: an empirical investigation', Journal of Marketing. 60:52 - 70.

Harvey, D. \& Brown, D. 2001. An experiential approach to organisation development. $6^{\text {th }}$ Edition. Prentice Hall, Upper Saddle River: New York.

Hellriegel, D., Jackson, S., Slocum, J., Staude, G. \& Associates. 2001. Management: South African edition. Cape Town: Oxford University Press.

Hodge, B.J., Anthony, W.P. \& Gales, L. 1996. Organisational Theory: A Strategic Approach. $5^{\text {th }}$ Edition. Upper Saddle River, New Jersey: Prentice Hall.

Hugo, A. 1997. 'Key developmental experiences in work context: A qualitative study of managers' perceptions'. MA dissertation, University of Pretoria.

Kelly, G.A. 1970. 'A brief introduction to personal construct theory'. In Bannister, D. (Ed.). Perspectives of personal construct theory. London: Academic Press.

Kelly, G.A. 1963. A theory of personality: The psychology of personal constructs. New York: Norton \& Co. 
Kelley, S.W. 1992. 'Developing customer orientation among service employees', Journal of the Academy of Marketing Science, 20: 27 - 36.

Koepp, S. 1987. 'Puleeze! Will somebody help me'. Time, Feb. 2: $28-34$.

Kotler, P. \& Armstrong, G. 2001. Principles of marketing. $9^{\text {th }}$ Edition. Upper Saddle River, New Jersey: Prentice Hall.

Kotze, M. 1999. 'Die identifisering van topbestuursparadigmas: 'n Kwalitatiewe analise.', Tydskrif vir Geesteswetenskappe, 39(2): 145 - 157.

Mason, J.B., Mayer, M.L. \& Ezell, H.F. 1991. Retailing. $4^{\text {th }}$ Edition. Homewood ILL:Irwin.

Mathieu, J.E.\& Zajac, D.M. 1990. 'A review and metaanalysis of the antecedents, correlates and consequences of organizational commitment', Psychological Bulletin, 108, $171-194$.

Nelson, T. \& Coxhead, H. 1997. 'Increasing the probability of re-engineering/culture change success through effective communication', Strategic Change, 6(1):29-48.

Ntsinde, N.M. 1995. 'Distinctive qualities of successful black managers'. MBA dissertation, Graduate School of Business Administration, University of the Witwatersrand.

Peppers, D. \& Rogers, M. 1999. 'The price of customer service', Sales \& Marketing Management, April: 20 - 21.

Robbins, S. 1992. Organisation theory. $6^{\text {th }}$ Edition. Englewood Cliffs, New Jersey: Prentice Hall.

Robbins, S.P. 1998. Organisational behaviour: Concepts, controversies and applications. $8^{\text {th }}$ Edition. Upper Saddle River, New Jersey: Prentice Hall.

Saxe, R. \& Weitz, B.A. 1992. 'The SOCO Scale: A measure of customer orientation of sales people', Journal of Marketing Research, 19: 343 - 351.

Smith, M., Hartley, L. \& Stewart, B.J.M. 1978. 'A case study of repertory grids used in vocational guidance', Journal of Occupational Psychology, 51: 97 - 104.

Smith, M. \& Stewart, B.J.M. 1977. 'Repertory grids: A flexible tool for establishing the content and structure of a manager's thoughts'. In Ashton, D. (Ed.). Management biographies and reviews, Vol.3. Yorkshire: MCB Press.

Spivey, W.A., Munson, J.A. \& Lacander, W.B. 1979. 'Meeting retail staffing needs via improved selection', Journal of Retailing, 55, Winter: $70-86$.

Steers, R.M. 1975. 'Problems on the measurement of organisational effectiveness', Administrative Science Quarterly, 20, Dec: 549 - 571.

Stewart, A. \& Stewart, V. 1976. Tomorrow's men today. London: Institute of Personnel Management.
Stewart, V. 1975. 'A technique for selection interviewing', Industrial Training International, 3: 179 - 181.

Stewart, V., Stewart, A. \& Fonda, N. 1981. Business applications of the repertory grid. London: McGraw-Hill.

Stoner, J.A. 1982. Management. 2 $2^{\text {nd }}$ Edition. Engelwood Cliffs, New Jersey: Prentice Hall.

Teas, R.K. 1981. 'A test of a model of department store sales peoples' job satisfaction', Journal of Retailing, 57(1): $3-23$.

Weatherby, K.A. \& Tansik, D.A., 1994. 'Tactics used by customer contact workers: effects of role stress, boundary spanning and control', International Journal of Service Industry Management 4:4 - 17.

Weitzel, W., Schmarzkorf, A.B. \& Peach, E.B. 1989. 'The influence of employee perceptions of customer service on retail store sales', Journal of Retailing, 65, Spring:

Weinberg, M.R. 1992. 'Chronic illness and the personal construction of the self: The case of myalgic encephalomyelitis'. MA dissertation, University of Cape Town.

Westbrook, R.A. 1981. 'Sources of customer satisfaction with retail outlets', Journal of Retailing, 57, Fall: 24 - 43.

Wetzels, M. de Ruyter, K. \& Bloemer, J. 2000. 'Antecedents and consequences of role stress of retail sales persons', Journal of Retailing and Consumer Serves, 7:65 75 .

Zaidel, M.V. 1995. 'Person-organisation fit: An organisational socialisation perspective'. MA dissertation, University of the Witwatersrand. 